\title{
ECOLOGICAL ASPECTS AND EGG PARASITISM OF THE TORTOISE BEETLE, CASSIDA VITTATA VILL., (COLEOPTERA: CHRYSOMELIDAE) ON SUGAR BEET IN DAKAHLIA GOVERNORATE
}

\author{
EL-SERWY, S. A. \\ Plant Protection Research Institute, ARC, Dokki, Giza
}

(Manuscript received 16 June 2008)

\begin{abstract}
The tortoise beetle, Cassida vittata Vill. (Coleoprera: Chrysomelidae) is a serious pest on sugar beet, Beta vulgaris L., in Egypt. Four free pesticides's fields were planted with Raspoly sugar beet variety to study some aspects of ecology and egg parasitism of this pest at Bilqas and Shirbin in Dakahlia governorate during 2004- 2005 and 2005- 2006 growing seasons. Obtained results proved that level and intensity of infestation, population density of larvae, pupae and adults and no. of deposited and parasitized eggs were fluctuated greatly. It ranged between about $64-73 \%$, 7- 9 feeding pores $/ 4 \mathrm{~cm}^{2}$ leaf disc, 6-9 individuals/leaf,12-16 eggs/leaf, and $19-29 \%$ at Bilqas and Shirbin, respectively. In both regions, the general means were about $70 \%$ infestation rate, 7 feeding pores $/ 4 \mathrm{~cm}^{2}$ leaf disc, 8 individuals or 17 eggs/leaf and $21 \%$ parasitized eggs in 2004- 05 opposed to $67 \%$ infestation rate, 8 feeding pores, 8 individuals or 11 eggs/leaf and $26 \%$ parasitized eggs in 2005- 06, with general means about $68 \%$ infestation rate, 8 feeding pores, 8 individuals or 14 eggs/leaf and $24 \%$ parasitized eggs. Feeding pores increased by increasing population density of larvae and adults reached its peak in early June. Ovipositional activity by $C$. vittata females as well as parasitic activity by the egg parasitoid Monorthochaeta nigra (Hymenoptera: Trichogrammitdae) started in mid March and continued until early June in both seasons. Deposited eggs peaked earlier and two weeks later than parasitized one in the first and the second seasons, respectively.
\end{abstract}

\section{INTRODUCTION}

The sugar beet, Beta vulgaris L., originated as the Mediterranean center where has been cultivated for thousands of years in one form or another, until the middle of the eighteenth century, when a German chemist discovered that its sugars was found to be identical to these of sugar cane (Chapman \& Carter, 1976). French agriculturalists were successful in raising strains of beets that could be processed to yield profitable amounts of sugar. This crop was planted in 186,396 feddans (feddan $=4200 \mathrm{~m}^{2}$ ) and produced $32 \%$ of all sugar production in Egypt. Of the total area, about $44 \%$ and $14 \%$ were planted in Kafr El-Sheikh and Daqahlia governorates, respectively (Anonymous, Ministry of Agric, 2006). Two feeding pores types of one or two openings on the leaf surfaces caused by adults and larvae of the tortoise beetle, 
Cassida vittata Vill. (Coleoptera: Chrysomelidae) and the white snail, Monacha obstructa (Pfeiffer) (Mollusca: Helicidae) were found in sugar beet fields at Bilqas and Shirbin regions in north Daqahlia, in 2004- 06 seasons. This beetle, is a very injurious insect pest. It causes reduction in root weight and sugar content. Adults are the most serious stage (Metwally et al, 1987; Mostafa et al, 1992 and Ebieda et al, 1996). Several authors contributed to C. vittata biology and ecology (Salama \& Elnagar, 1992; Samy et al, 1992; Aly et al, 1993a and 1993b; Abdel- Raheem, 2000 and Abo El-Naga, 2004). Few studies concerning the role of Monorthochaeta nigra Blood \& Kryger (Hymenoptera: Trichogrammatidae) as egg parasitoid on this pest have been conducted (Abo-Aiana,1991; Awadalla, 1993; El-Agamy et al, 1994 and Zawrah, 2000).

The present study was initiated to determine infestation level, no. of feeding pores on infested leaves (intensity of infestation), seasonal fluctuations of different stages of Cassida vittata as well as deposited and parasitized eggs at Bilqas and Shirbin regions in Daqahlia governorate in 2004-2005 and 2005-2006 sugar beet growing seasons.

\section{MATERIALS AND METHODS}

To assess seasonal fluctuations of $C$. vittata, four fields were planted with Raspoly sugar beet, Beta vulgaris, variety at Bilqas and Shirbin in Dakahlia governorate (Middle Nile Delta) in 2004-2005 and 2005-2006 growing seasons. Sowing dates were October (15 \& 10) at Bilqas and (19 \& 25) at Shirbin in 2004 and 2005, respectively. All recommended agricultural practices were made and no insecticides were used. Thirty leaves were randomly collected biweekly from March 12 to June 4, 2005 and 2006 at Bilqas and Shirbin. Samples were transferred to the laboratory to determine:

\section{1- Level and intensity of infestation:}

To asses the level of infestation each leaf was visually examined and classed as pored (infested) and non pored leaves (non infested). While intensity of infestation were evaluated by counting the number of feeding pores on four discs $(2 \times 2 \mathrm{~cm}=4$ $\mathrm{cm}^{2}$ each) per leaf every two weeks till the end of the season.

\section{2- Population density of larvae, pupae and adults:}

Number of larvae, pupae and adults on both leaf surfaces were counted, also those found inside the collection sac were counted.

\section{3- Deposited and parasitized eggs:}

Deposited eggs on both leaf surfaces were counted and classified into eggs with exit hole (parasitized eggs) and eggs without exit hole. 
To assess egg parasitism, parasitized eggs were excluded and the remained ones were maintained on a piece of sugar beet leaf and placed into petri dishes $(5 \mathrm{~cm}$ in diameter) containing a piece of moistened cotton wool. Emerged parasitoids were counted and recorded. In each collection date, rate of parasitism was calculated by using the following formula:

\section{No. of parasitized eggs}

\section{Rate of parasitism $=$} X 100

\section{Total number of parasitized and non-parasitized eggs}

Relationship between the two variables no. of feeding pores $(y)$ and no. of larvae and adults $(x)$ as well as rate of parasitized eggs $(y)$ and no. of deposited eggs (x) on the sugar beet plant ages at Bilqas and Shirbin in 2004- 2005 and 2005- 2006 sugar beet growing seasons were determined by using the simple regression statistical analysis. Estimated (ỳ) calculated by applying the following formula: $\grave{y}=y$ $+b\left(x-x^{-}\right)$and the fittings of the linear regression are represented. The calculated correlation coefficient $(r)$ used to measure the closeness of relationship between each two variables in each region in both seasons.

\section{RESULTS AND DISCUSSION}

The general means of level and intensity of infestation, the population density of larvae, pupae and adults, numbers of deposited per leaf and rate of egg parasitism of Cassida vittata at Bilqas and Shirbin in 2004- 2005 and 2005- 2006 sugar beet growing seasons are summarized in Table 1. During the course of this study, the level and intensity of infestation as well as the population density of larvae, pupae and adults were higher at Shirbin than at Bilqas. The general means were 72.8 \& 63.9\%; $8.5 \& 6.7$ feeding pores $/ 4 \mathrm{~cm}^{2}$ leaf disc and $8.9 \& 6.3$ individuals/leaf, respectively. Infestation level fluctuated from 66.3 to $61.4 \%$ at Bilqas and from $73.1 \%$ to $72.4 \%$ at Shirbin during 2004-05 and 2005-06, respectively. The grand general mean of infestation level was about $68 \%$, 8 feeding pores per $4 \mathrm{~cm}^{2}$ leaf disc and 8 individuals per leaf.

\section{1- Incidence of infestation level:}

In mid March of 2005, the initial infestation levels were 8 and $13 \%$, four weeks later, the levels had increased to 36 and $66.7 \%$ in Bilqas and Shirbin, respectively (Fig. 1). It reached a maximum of $100 \%$ after two weeks and the same level continued until early June at both regions. In 2006, the initial levels were 11 and $22 \%$ increased to 65 and $90 \%$ in the third week of April and early May, two weeks later, levels reached $100 \%$ in Bilqas and Shirbin, respectively (Fig. 1). 


\section{2- Incidence of intensity of infestation:}

Intensity of infestation can be expressed by the feeding pores caused by larvae and adults of $C$. vittata. In mid March of 2005, the initial number was about 1 feeding pore $/ 4 \mathrm{~cm}^{2}$ leaf disc, increased gradually reached a peak about 15 and 17 feeding pores $/ 4 \mathrm{~cm}^{2}$ leaf disc in early June in Bilqas and Shirbin, respectively, but lowered to about 4 in early May at Bilqas (Fig. 2 ). In 2006, feeding pores ranged between about 3- 18 and 2- 17 per $4 \mathrm{~cm}^{2}$ leaf disc from mid March to early June at Bilqas and Shirbin, respectively. Whereas, a slightly decrease of about $7 / 4 \mathrm{~cm}^{2}$ leaf disc was attained in early May in Bilqas (Fig. 2 ).

\section{3- Population density of larvae, pupae and adults:}

Population density of larvae, pupae and adults followed a similar pattern of incidence at both regions. In mid March of 2005, the initial number was about 2 per leaf, increased gradually reached a peak about 13 and 14 in early June in Bilqas and Shirbin, respectively(Fig. 3. ). In 2006, individuals ranged between about 2- 16 and 4- 12 per leaf from mid March to early June at Bilqas and Shirbin, respectively. Whereas, a slightly decrease of about 4 leaf was recorded in early April in Shirbin (Fig. $3)$.

These results indicate that level and intensity of infestation as well as population density of larvae, pupae and adults were higher in Shirbin than in Bilqas during the course of this study. Infestation started in a low level in mid March increased gradually with the increase of plant age and reached a maximum of $100 \%$ in late April 2005 at both regions, but delayed two and four weeks in Bilqas and Shirbin in the next year. In both regions, feeding pores as a parameter of intensity of infestation and population density of larvae and adults feeding stages followed a similar pattern of incidence reaching its peaks in early June in both seasons. Relation found between the two variables and its closeness was higher at Bilqas than at Shirbin. The regression coefficient $(r)$ values and equations were $(0.9782 \& 0.9738$ and $\grave{y}=-0.8+1.2 x \& \grave{y}=-0.8+1.15 x$ ) at Bilqas opposed to $0.8038 \& 0.8177$ and $\grave{y}=-2.7+1.16 \times \& \grave{y}=-4.3+1.56 x$ ) at Shirbin in 2005 and 2006, respectively. The fitting of the regression lines show that the feeding pores increased by increasing the population density of larvae \& adults and the plant age at Bilqas (Fig. 4, A) and at Shirbin (Fig. 4, B) during 2004-2005 and 2005-2006 sugar beet growing seasons. These results are in agreement with those obtained by ( Samy, et al, 1992; Aly et al, 1993b; Abdel-Raheem, 2000 and Abo El-Naga, 2004). 


\section{4- Incidence of deposited and parasitized eggs:}

Females lays singly eggs or in small groups of 2, 3 and 4 adjacent to the leaf veins and inside the old feeding pores at both leaf surfaces which covered and fitted with sticky transparent protective gelatinous membrane. Majorities ( $>61 \%$ ) of deposited eggs laid in a cluster of two eggs and (> 73\% ) was found on the lower leaf surface during the course of this study.

The number of deposited eggs was higher at Shirbin than at Bilqas with general means about 16 and 12 per leaf and a grand general mean of 14 eggs/leaf (Table 1). It fluctuated from about 13 to 22 per leaf at Bilqas and Shirbin during 2004- 2005 season, respectively, but was about 11 per leaf at both regions in 20052006 season. Ovipositional activity by females started in low numbers as about 2 per leaf in mid March, reached a peak of about 53 and 39 in the third week of April and early May and drastically lowered to about 11 and 6 per leaf in early June at Shirbin and Bilqas in 2005, respectively (Fig. 5). In mid March of 2006, the initial numbers were about $11 \& 4$, reached a peak of 17 and 21 in the third week of April and May and lower to 7 and 6 after six and two weeks at Shirbin and Bilqas, respectively (Fig. $5)$.

Parasitized eggs was higher at Shirbin than at Bilqas with general means of 28.5 and $18.9 \%$, respectively and a grand general mean of $23.7 \%$ (Table 1 ). Parasitized eggs fluctuated greatly from 13.9 to $24 \%$ at Bilqas during 2005 and 2006, respectively, whereas decreased to less than $1 \%$ during the same period at Shirbin.

Parasitic activity by the egg parasitoid, Monorthochaeta nigra Blood \& Kryger (Hymenoptera, Trichogrammatidae), started in low rates about 4 and $2 \%$ in mid March, reached a peak of 57.4 and $28.9 \%$ in early May and June 2005 in Shirbin and Bilqas, respectively, but decreased to $29.1 \%$ after a month at Shirbin (Fig. 6). In mid March of 2006, the initial rates were about 14 and 6\%, reached a peak of 36.7 and $35.9 \%$ in early April and May and declined to about $29 \%$ after eight and four weeks in Shirbin and Bilqas, respectively (Fig. 6).

These results indicate that deposited and parasitized eggs were fluctuated greatly with general means ranged between 12.1- 16.4 eggs per leaf and 18.9$28.5 \%$ at Bilqas and Shirbin with grand general means of 14.2 eggs per leaf and $23.7 \%$ at mentioned regions, respectively. In both regions, increasing number of deposited eggs in 2005 accompanied with lower parasitism and the opposite was true in the next year. The general means of deposited were 17.3 and 11.2 eggs per leaf versus to 21.4 and $26 \%$ of parasitized eggs in 2005 and 2006, respectively. Relation existed between the numbers of deposited and parasitized eggs which rate of parasitism decreased by increasing the number of deposited eggs and its closeness was generally lower. The regression coefficient $(r)$ values and equations were $(0.5688 \& 0.6968$ and $\grave{y}=8.15+0.45 x \& \grave{y}=8+1.4 x)$ at Bilqas and $(0.6088 \&$ 0.4442 and $\grave{y}=15.8+0.6 \times \& \dot{y}=17+1 x$ ) at Shirbin in 2005 and 2006, 
respectively. The fittings of regression lines indicate that the parasitized eggs slightly decreased by increasing the number of deposited eggs at Bilqas (Fig. 7, A) and at Shirbin (Fig. 7, B) during 2004-2005 and 2005-2006 sugar beet growing seasons. This results are in agreement with the findings of (Awadalla, 1996 and Zawarh, 2000).

It is clearly that, parasitic activity started in low rates in mid March and continued until early June reached its peaks (in early April and May) at Shirbin and (in early May and June) at Bilqas in 2006 and 2005, respectively. The general mean of parasitized eggs was $23.7 \%$ which relatively higher when compared to 8 and $13 \%$ obtained in Kafr El-Sheikh governorate by ( Abo-Aiana, 1991 and El-Agamy et al, 1994) and (16.5 \& 14.5\%) at Mansoura in Daqahlia governorate by (Awadalla,1993 and Zawrah, 2000). It is noteworthy to mention that, rates of parasitized eggs 4.2, 20.5 and $13.5 \%$ were attained in the third week of April and May as well as late May at Sinbellawein (south Daqahlia), Kafr Saad (Dimieeta governorate) and Sakha (Kafr El-Shikh governorate), respectively (El-Serwy, unpublished data, 2005).

In conclusion, level and intensity of infestation, population density of larvae, pupae and adults as well as number of deposited eggs and parasitized eggs were fluctuated greatly. It ranged between about $64-73 \%$ infestation rate, 7-9 feeding pores/4 $\mathrm{cm}^{2}$ leaf disc, 6-9 individuals or 12-16 eggs/leaf, and 19-29\% parasitism rate at Bilqas and Shirbin, respectively. The grand general means were about $68 \%$ infestation rate, 8 feeding pores/ $4 \mathrm{~cm}^{2}$ leaf disc or 8 individuals per leaf, 14 eggs/leaf and $24 \%$ parasitized eggs. Infestation started in low level by mid March, reached $100 \%$ in late April 2005 in both regions or the first and third weeks of May 2006 in Bilqas and Shirbin, respectively, the same level continued until early June in both years. Feeding pores increased by increasing population density of larvae and adults reached its peak in early June in each region in both years. Ovipositional activity by C. vittata females as well as parasitic activity by the egg parasitoid Monorthochaeta nigra resulted in lower deposited and parasitized eggs in mid March and continued until early June where deposited eggs peaked earlier and two weeks later than parasitized one in the first and the second seasons, respectively. The closeness between the population density of larvae $\&$ adults and feeding pores was higher than those found between deposited and parasitized eggs at both regions. Feeding pores increased by increasing the population density of larvae and adults. On the other hand, the percentage of egg parasitism by $M$. nigra decreased as the host density increased which retarded the biological control against this pest. Therefore, to conserve and promote this egg parasitoid insecticides must be entirely avoided and early planting during August and September could be followed for sugar beet crop as one of the best agricultural control method (El-Serwy, 2008). 
Table 1. Overall and general means of different aspects of Cassida vittata at Bilqas and Shirbin regions during 2004-2005 and 2005-2006 sugar beet growing seasons.

\begin{tabular}{|c|c|c|c|c|c|c|c|c|c|}
\hline \multirow{3}{*}{ Aspects of } & \multicolumn{6}{|c|}{ Overall means during } & \multicolumn{2}{|c|}{ General means at } & \multirow{3}{*}{$\begin{array}{r}\text { Grand } \\
\text { genera } \\
\text { mean }\end{array}$} \\
\hline & \multicolumn{3}{|c|}{ 2004-2005 at } & \multicolumn{3}{|c|}{$2005-2006$ at } & \multirow[b]{2}{*}{ Bilqas } & \multirow[b]{2}{*}{ Shirbin } & \\
\hline & Bilqas & Shirbin & $\begin{array}{c}\text { General } \\
\text { mean }\end{array}$ & Bilqas & Shirbin & $\begin{array}{c}\text { General } \\
\text { mean }\end{array}$ & & & \\
\hline Infestation in rate & 66.3 & 73.1 & 69.7 & 61.4 & 72.4 & 66.9 & 63.9 & 72.8 & 68.3 \\
\hline $\begin{array}{l}\text { Intensity of infestation } \\
\text { represented by feeding } \\
\text { pores } / 4 \mathrm{~cm}^{2} \text { leaf disc }\end{array}$ & 5.8 & 8.5 & 7.2 & 7.5 & 8.6 & 8.0 & 6.7 & 8.5 & 7.6 \\
\hline $\begin{array}{l}\text { Population density of larvae, } \\
\text { pupae and adults per leaf }\end{array}$ & 5.5 & 9.7 & 7.6 & 7.2 & 8.2 & 7.7 & 6.3 & 8.9 & 7.6 \\
\hline Eggs per leaf & 12.8 & 21.8 & 17.3 & 11.4 & 11.0 & 11.2 & 12.1 & 16.4 & 14.2 \\
\hline Parasitized eggs in rate & 13.9 & 28.9 & 21.4 & 24.0 & 28.1 & 26.0 & 18.9 & 28.5 & 23.7 \\
\hline
\end{tabular}




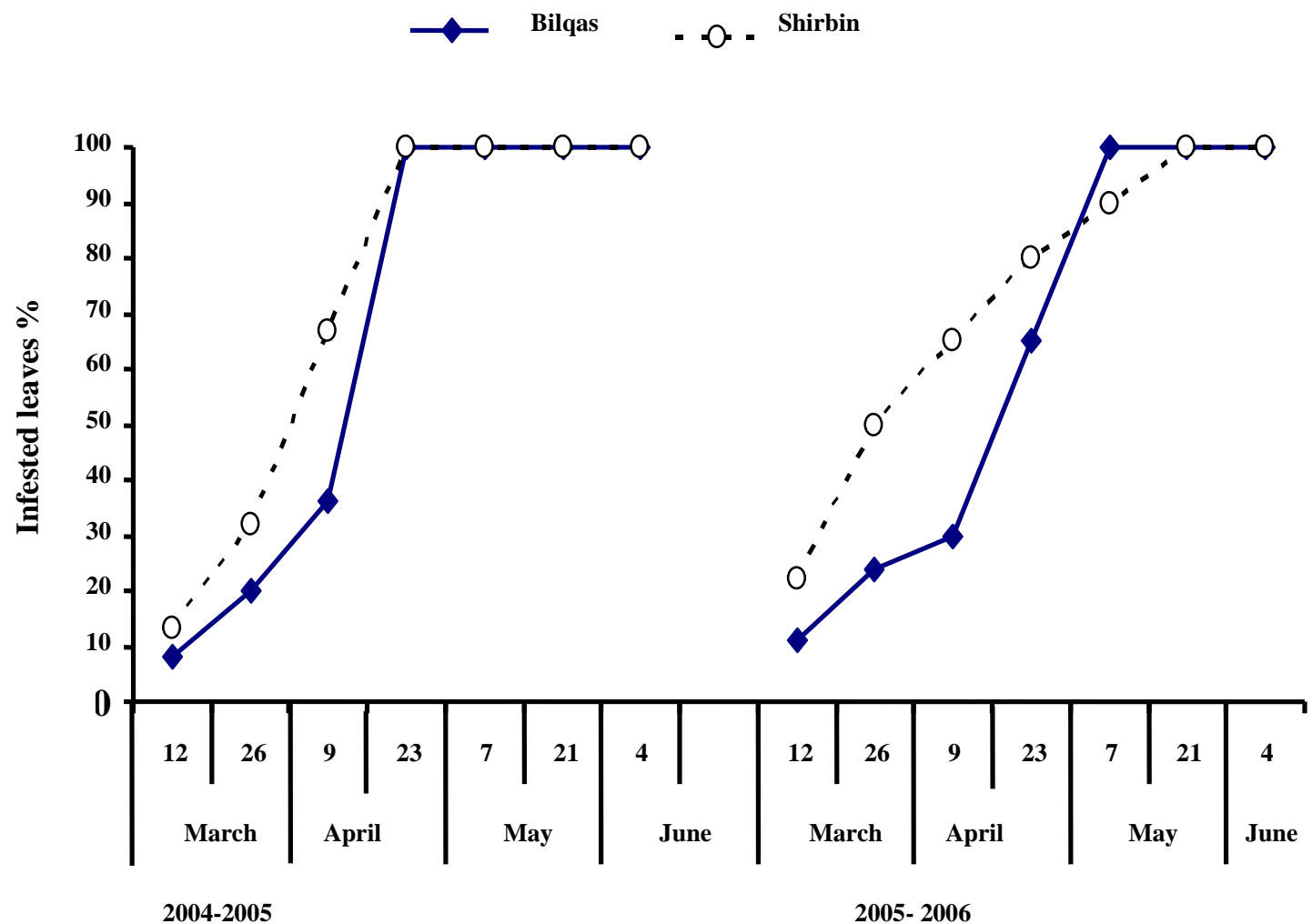

Sampling date

Fig. 1. Infestation level of Cassida vittata at Bilqas and Shirbin during March- June in 2004- 05 and 2005- 06 sugar beet growing seasons. 
EL-SERWY, S. A.

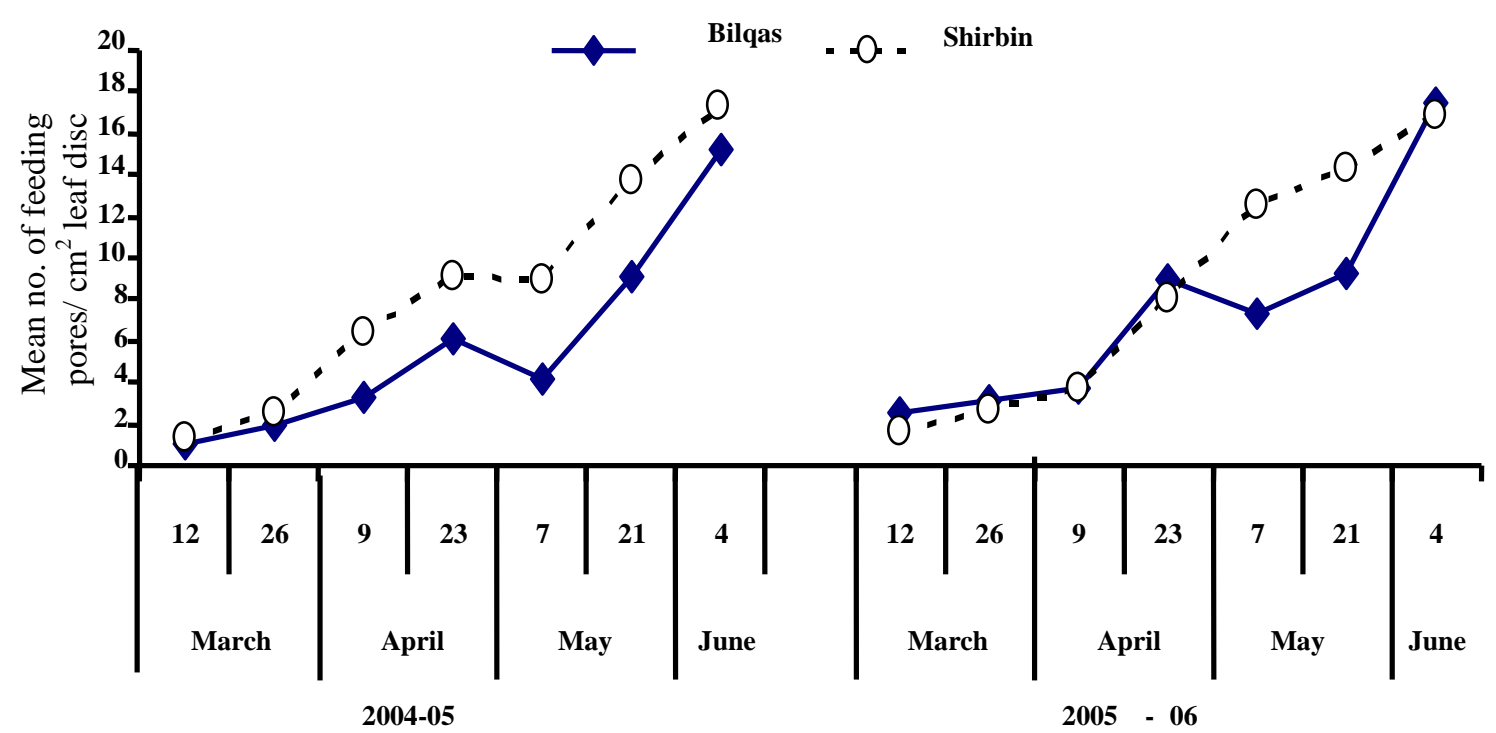

Sampling date

Fig. 2. Mean no. of pores caused by feeding larvae and adults of Cassida vittata at Bilqas and Shirbin during March- June in 2004-05 and 2005- 06 sugar beet

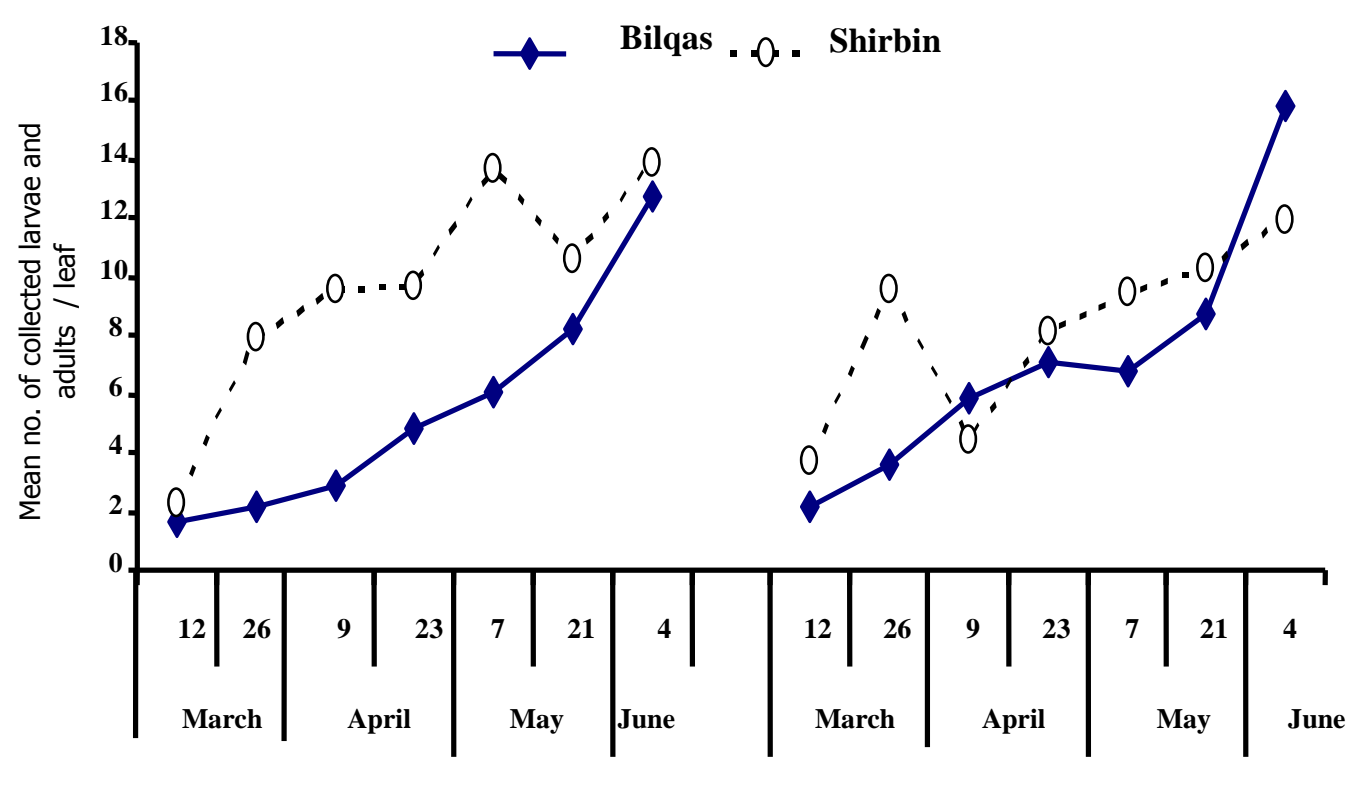

2004-05

2005- 06

Collection date

Fig. 3. Population density of Cassida vittata larvae, pupae and adults at Bilqas and Shirbin during March- June in 2004- 05 and 2005- 06 sugar beet growing seasons. 
- - - - Larvae and adults (x) - Estimated feeding pores (y)

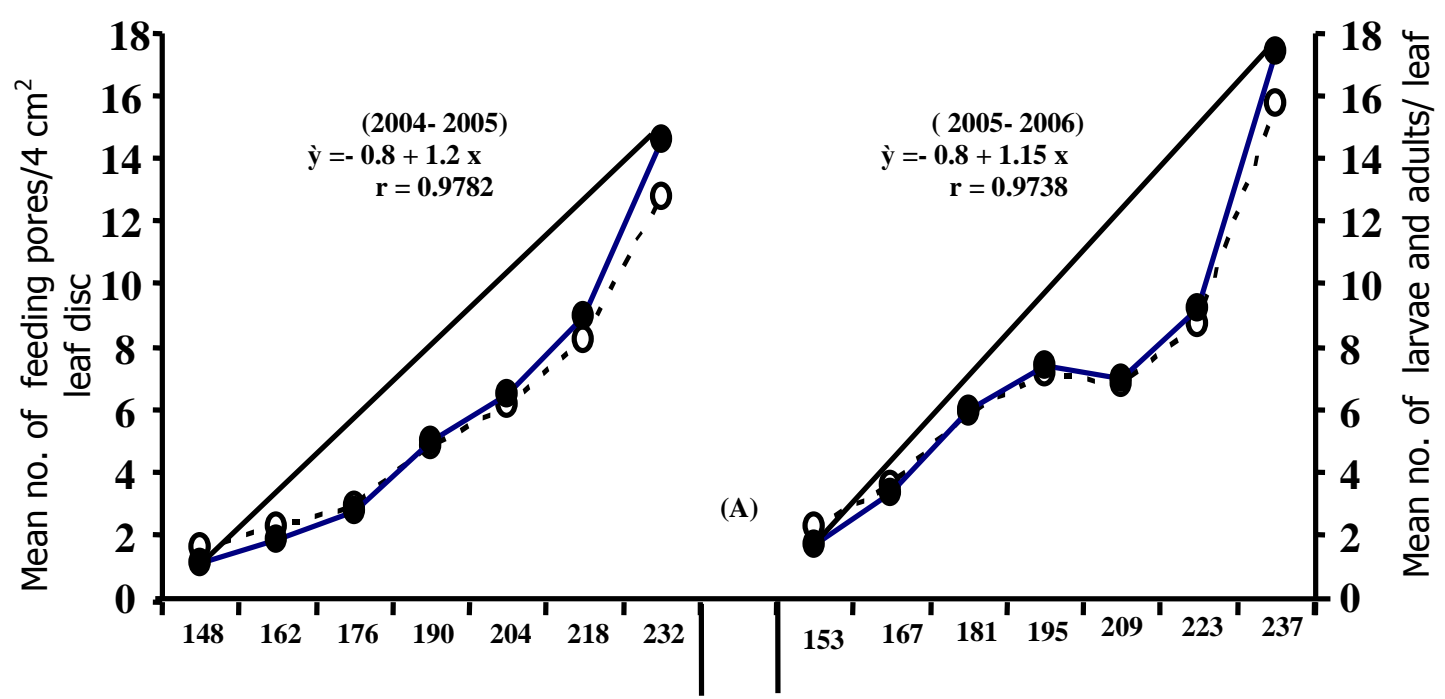

Plant age (in days)

- 0 - Larvae and adults $(x)-1$ Estimated feeding pores $(\grave{y})$

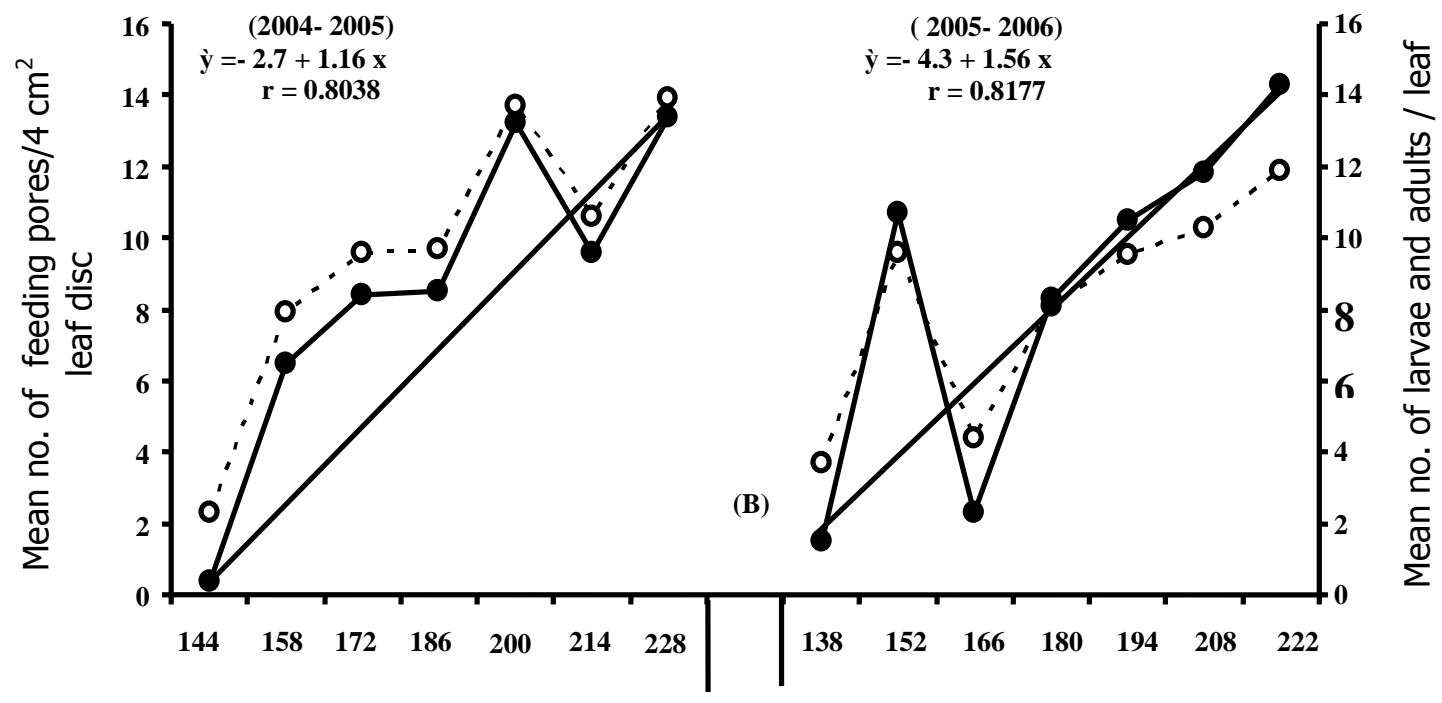

Plant age (in days)

Fig. 4. Relation between population density of larvae and adults of Cassida vittata and feeding pores at Bilqas (A) and Shirbin (B) on age progress of plants during 2004-2005 and 2005-2006 sugar beet growing seasons. 
EL-SERWY, S. A.

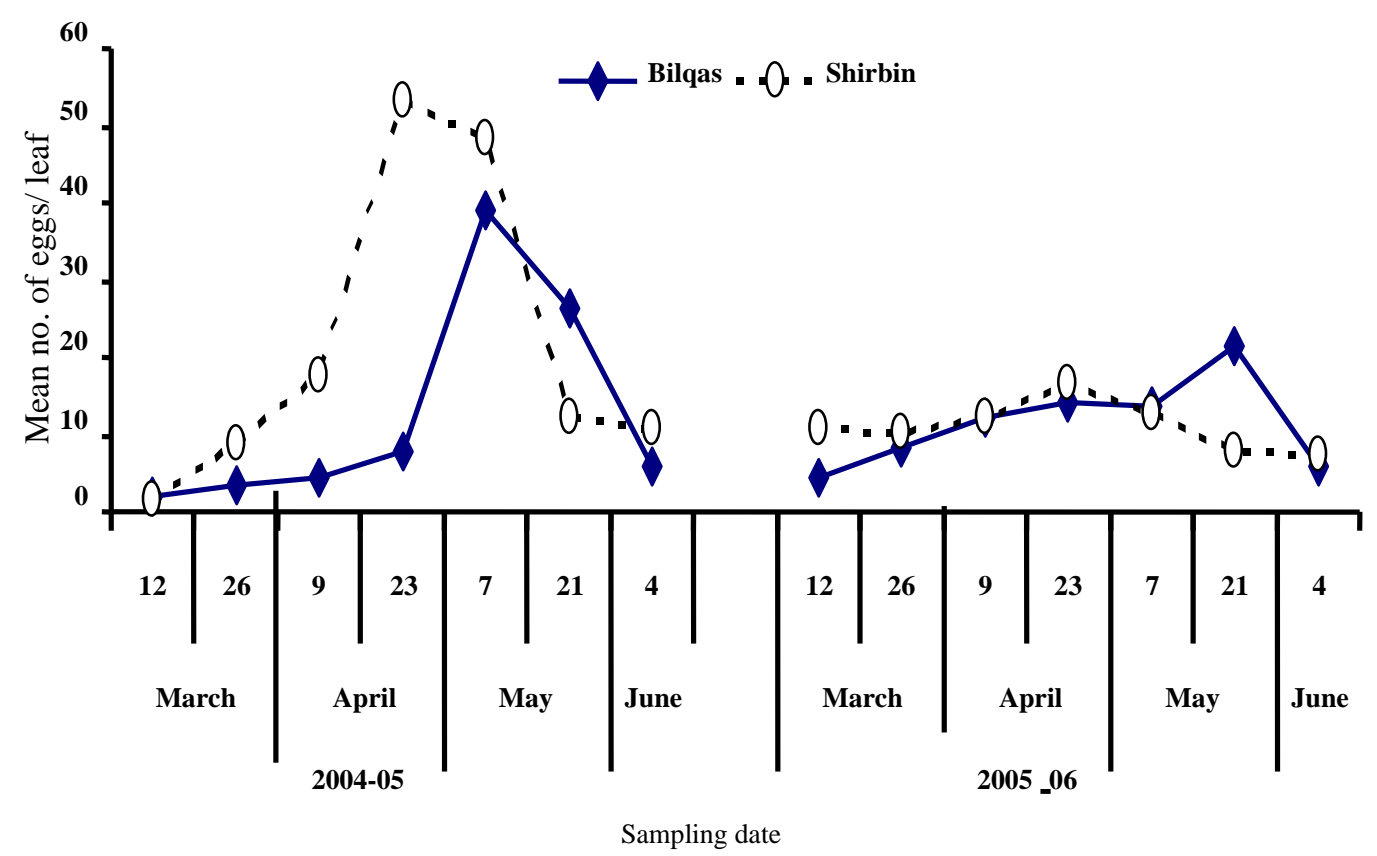

Fig. 5. Mean no. deposited eggs by Cassida vittata females per leaf at Bilqas and Shirbin during March- June in 2004- 05 and 2005- 06 sugar beet growing seasons.

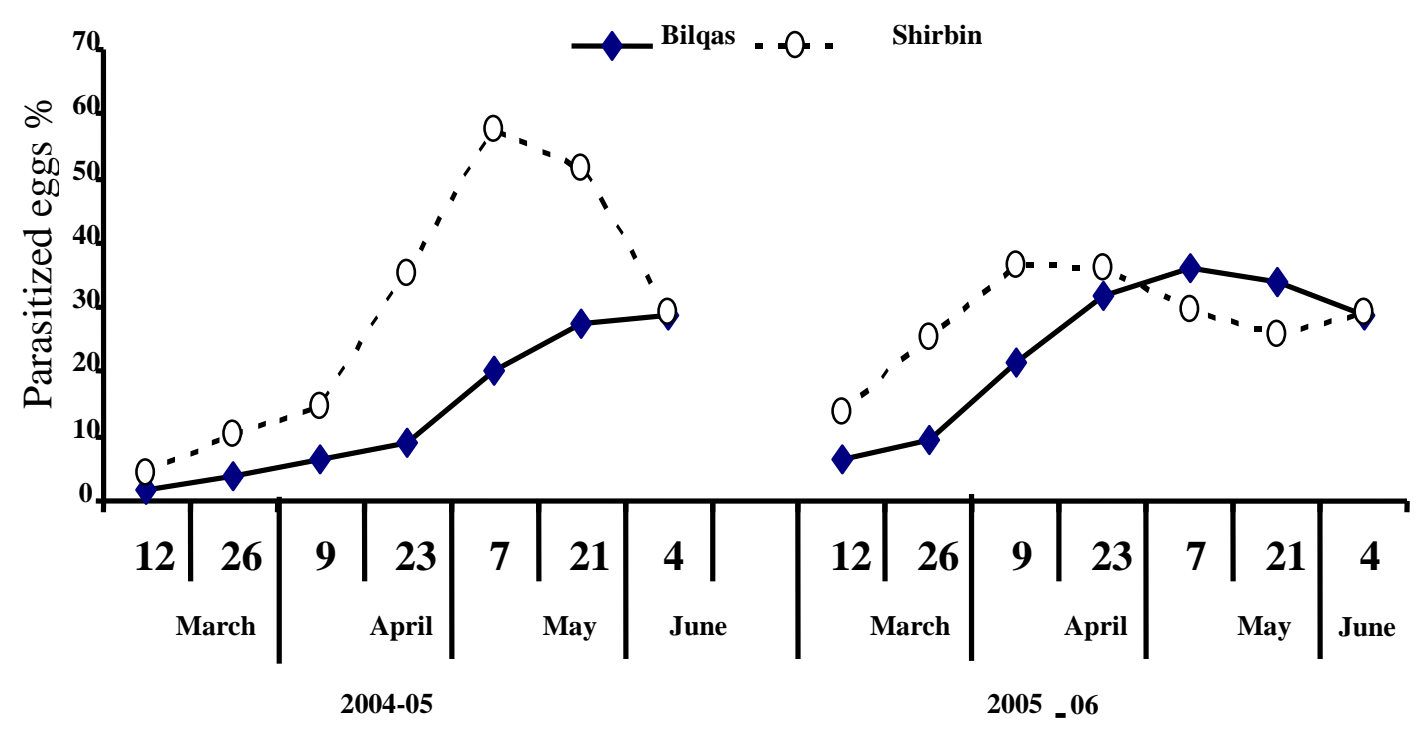

Sampling date

Fig. 6. Incidence of egg parasitism by the egg parasitoid Monorthochaeta nigra at Bilqas and Shirbin during March- June in 2004- 05 and 2005- 06 sugar beet growing seasons. 
- $\mathbf{0}$ - Deposited eggs (x) - $\quad$ Estimated parasitized eggs \% (ỳ)

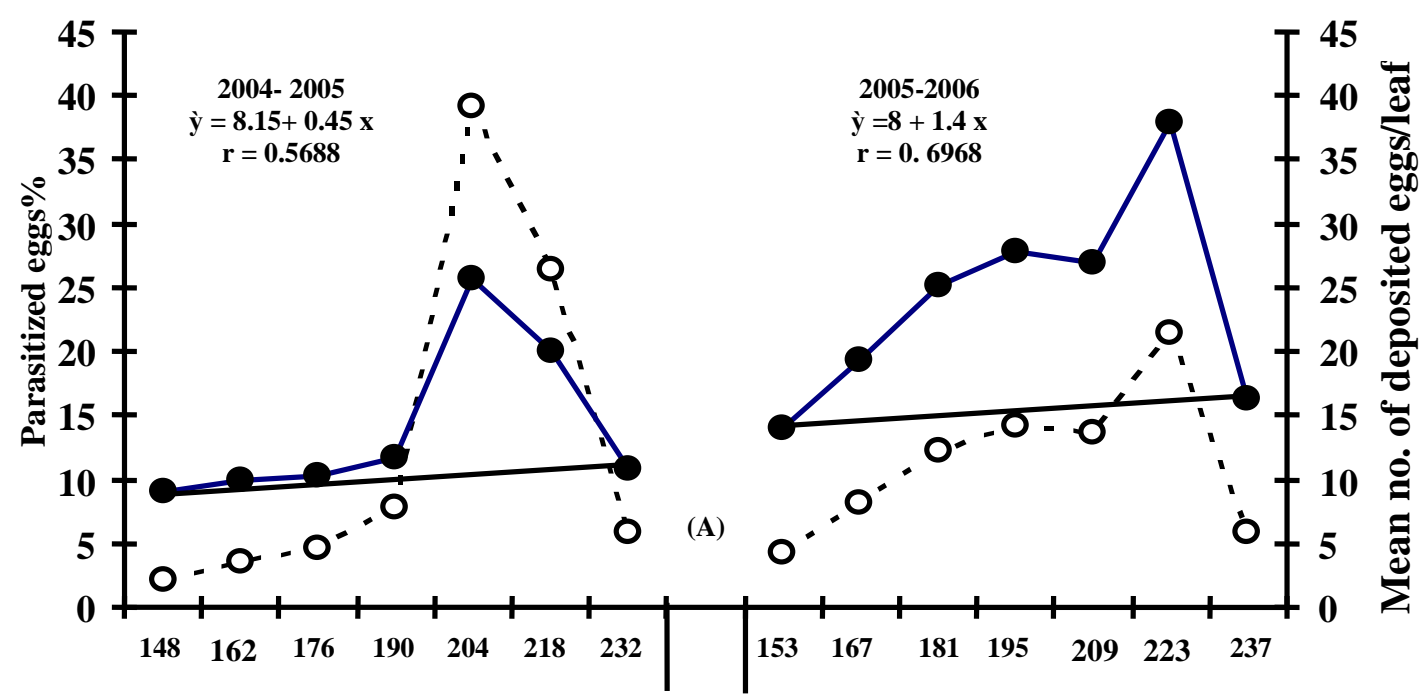

Plant age (in days)

- - Deposited eggs $(x)$

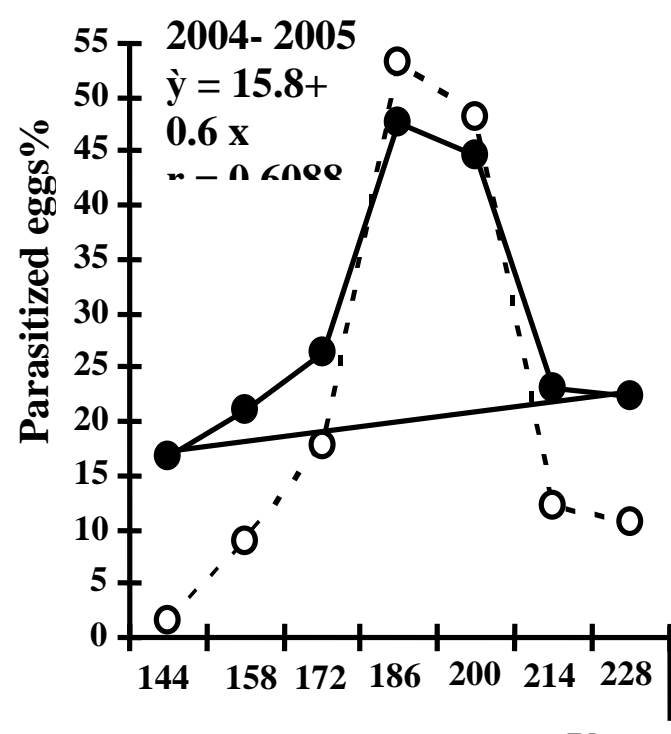

Estimated parasitized eggs \% (ì)

\section{5- 2006}

$\grave{\mathbf{y}}=17+1 \mathrm{x}$

$\mathrm{r}=\mathbf{0 . 4 4 4 2}$

(B)

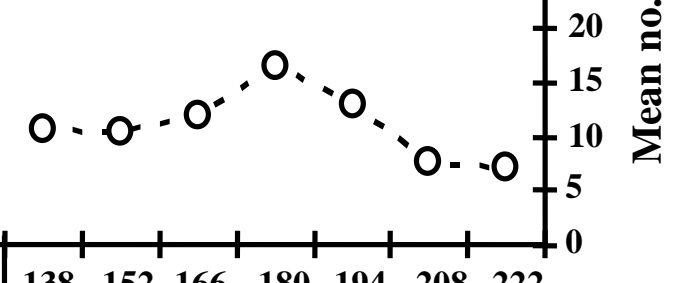

Plant age (in days)

Fig. 7. Relation between deposited eggs by Cassida vittata and parasitized egg by Monorthochaeta nigra at Bilqas (A) and Shirbin (B) during 20042005and 2005- 2006 sugar beet growing seasons. 


\section{REFERENCES}

1. Anonymous, Ministry of Agriculture and Land Reclamation. 2006. Sugar Crops Council, Annual, report: 264pp (In Arabic).

2. Abdel- Raheem, M. A. A. 2000. Ecological and biological aspects of certain key pests of sugar beet in Egypt. M. Sc. Thesis, Fac. of Agric., Cairo Univ., 73pp.

3. Abo-Aiana, R. A. D. 1991. Studies on pests of sugar beet in Kafr El-Sheikh. Ph. D., Fac. of Agric., Tanta Univ., 171 pp.

4. Abo El-Naga, A. M. M. 2004. Ecological studies and integrated control of the sugar beet beetle, Cassida vittata de Villers. M. Sc. Fac. of Agric., Tanta Univ., 129 pp.

5. Aly, F. A., M. A. Samy, F. E. El-Adl and S. M. Ibrahim.1993a. Effect of planting dates on the infestation ratio of the main insect in sugar beet fields. J. Agric. Sci., Mansoura Univ., 18(6): 1805- 1812.

6. Aly, F. A., M. M. A. Mahgoub, S. I. El-Deib and M. A. El- Hamaky1993b . Biological studies on the tortoise beetle, Cassida vittata Vill., and the efficacy of certain chemicals in controlling this insect in sugar beet plants. J. Agric. Sci., Mansoura Univ., 18(6): 1813-1824.

7. Awadalla, S. S. 1993. Abundance of the tortoise beetle, Cassida vittata Vill., and role of parasitoids on their immature stages. J. Agric. Sci., Mansoura Univ., 18 (8): 2436- 2440. ; Awadalla, 1993

8. Awadalla, S. S. 1996. Biological studies on Monorthochaeta nigra Blood \& Kryger (Hymenoptera, Trichogrammatidae) as egg parasitoid on the tortoise beetle, Cassida vittata Vill. (Coleoptera: Chrysomelidae). J. Appl. Ent. 120: 353- 355.

9. Chapman, S. R. \& L. P. Carter. 1976. Crop production, principles and practices. W. H. Freeman and Company, San Francisco: 566 pp.

10. Ebieda, A. M. M., M. A. Hassanein and A. G. Solouma. 1996. Studies on sugar beet pests. IV. Biophysiological parameters and new approaches of tortoise beetle, Cassida vittata Vill. and beet fly Pegomyia mixta Vill. Annals of Agric. Sc. Moshtohor, 34 (3): 1213- 1228.

11. El-Agamy, F. M., S. M. I. Metwally, R. El-Sufty and A. Youssef. 1994. On role of parasitoids of the sugar beet beetle, Cassida vittata de Villers in Kafr El-Sheikh Governorate, Egypt. Egypt. J. Biol. Pest Control 4 (2): 33- 38.

12. El-Serwy, S. A.2008. Relation between planting date and Cassida vittat Vill. (Coleoptera: Chrysomeildae) infestation in sugar beet fields. Egyp. J. Agric. Res.(In press). 
13. Metwally, S. M. I., R. El-Sufty, N. El- Dakhakhny and A. Bassiouny. 1987. Effect of infestations with certain insect pests on some sugar beet properties. J. Agric. Res. Tanta Univ., 13(4): 1119- 1128.

14. Mostafa, F. F., R. A. K. Salama, L. A. Hemida and S. Elnagar. 1992. Foliage consumption by tortoise beetle, Cassida vittata Vill. and economic injury level to sugar beet yield. Fayoum J. Agric. Res. \& Dev., 6 (1): 14- 24.

15. Salama, R. A. K. and S. Elnagar. 1992. The tortoise beetle, Cassida vittata Vill. (Coleoptera: Chrysomelidae), a possible pest of sugar beet plantations in Egypt. J. Appl. Ent., 113: 88-92.

16. Samy, M. A. E., K. A. A. Draz and M. H. M. El-Khawalka. 1992. Seasonal fluctuation of Cassida vittata and Pegomyia mixta and their predators in certain sugar beet varieties plantation at Sakha, Egypt. J. Agric. Sci., Mansoura Univ., 17 (9): 3059- 3064.

17. Zawrah, M. F. M. 2000. Studies on some insect pests infesting sugar beet and their natural enemies. M. Sc. Fac. of Agric., Mansoura Univ., 74 pp. 


\section{المظاهر البيئية و تطقل البيض لخنفساء البنجر السلحفائية \\ على بنجر السكر في محافظة الاقهلية.}

$$
\text { سمير عوض السروى }
$$

$$
\text { معهر بحوث وقاية النباتات- مركز البحوث الزراعية- دقي- جيزة }
$$

تعتبر خنفساء البنجر السلحفائية من رتبة غمديه ألأجنحة وفصيلة كرايسوميليدى آفة خطيرة على بنجر

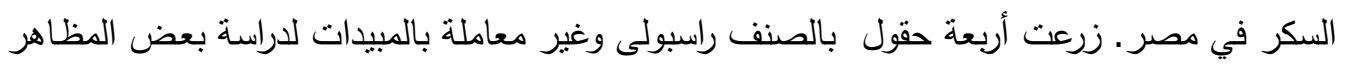

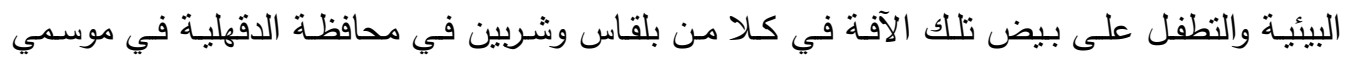

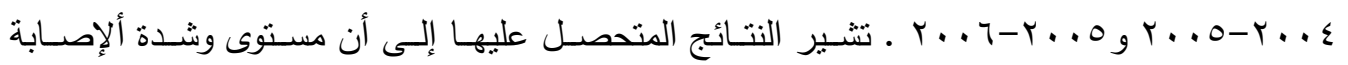
والكثافة العددية لليرقات ،العذارى والحشرات البالغة و كذلك أعداد البيض الموضوع والمتطفل علية قد

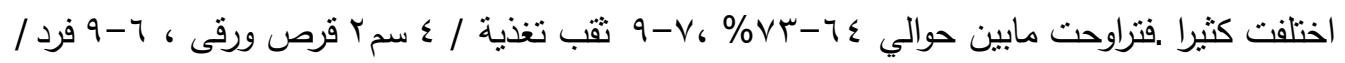

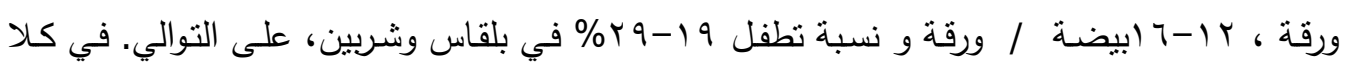

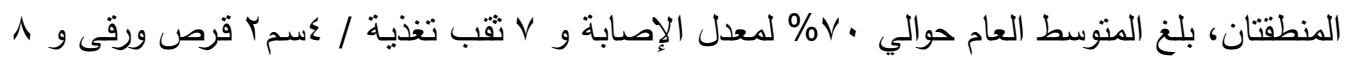

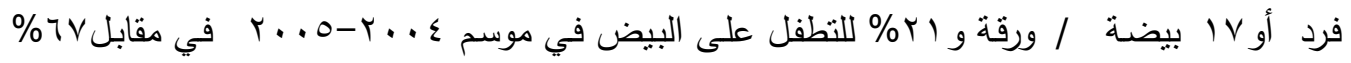

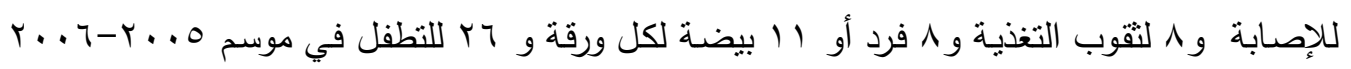

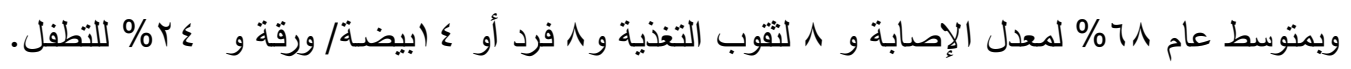

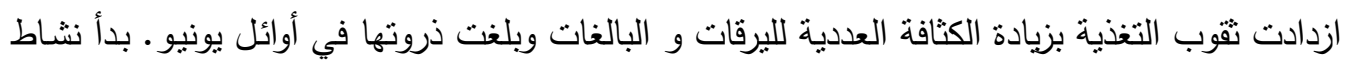

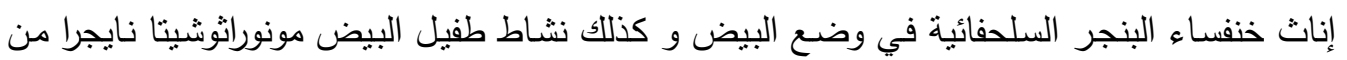
رتبة غشائية ألأجنحة وفصيلة نرايكوجراماتييدى في منتصف مارس واستمرا نشاطهما حتى أوائل يونيو

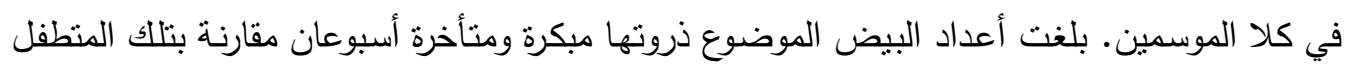
عليها في الموسمين ألأول والثاني، على التوالي. 